\section{The correlation between parenting style and child creativity development}

\author{
Eppy Setiyowati, ${ }^{1}$ Umi Hanik, ${ }^{2}$ \\ Mujadidien Affandi ${ }^{2}$
}

${ }^{1}$ Departement of Nursing Community, and ${ }^{2}$ Departement of Fundamental Nursing, Nursing and Midwifery Faculty, Universitas Nahdlatul Ulama Surabaya, Indonesia

\begin{abstract}
Many children experience problems with creativity development. The purpose of this study was to analyze the correlations between parenting style and the creative development of their child. The study was performed on students of TK RA Al-Islah (Kindergarten). A school located in Patuk, Gempol Sub-district, Pasuruan. The design used an analytic cross sectional study. The population was 32 mothers who had children between the ages of 4 and 5. The data was collected using a questionnaire and analyzed using Fischer's Exact test with the significance level $\alpha=0.05$. The study showed that nearly half of mothers $(40.0 \%)$ applied permissive parenting style and $56.7 \%$ children had low creativity development. The result of the analysis showed a correlation between a mother's parenting style and the creativity development of their child, $\mathrm{p}(0.016)<\alpha(0.05)$. The conclusion of the study was that child creativity development is positively influenced by productive parenting styles. Hence, parents are expected to apply better parenting styles to their children, for achieving better child creativity development.
\end{abstract}

\section{Introduction}

Parenting style is the form or system by which one takes care of a child. Using this terminology, parenting is a form and system used to refer to taking care of and educating a child consistently. Children can react to parenting behavior in either positive or negative ways. ${ }^{1}$ Parental accompaniment is the manifestation of child education. The way parents educate their children is called parenting. Interaction between parents and children tend to be done using the best method, for the sake of the child. There are many different parenting styles, however parents must choose the appropriate parenting style for their child's needs. ${ }^{2}$

Parenting refers to the interaction between a child, and their parents. Whereby, through this interaction, a parent educates their child. The parent provides them with guidance and discipline until they reach maturity according to social norms. Parenting can be defined as the whole treatment applied by parents to the child. Many experts claim that parenting is an important and basic action to prepare a child to be a good member of society. Parenting is a process of interaction between parents and children. This interaction covers the actions of caretaking, such as providing a child with food, motivating them to achieve success, and teaching them which behaviors are accepted by society. ${ }^{3}$

Creativity development refers to a child's ability to do new things. Child creativity development is measured in curiosity, self-confidence, interaction ability, motivation, responsibility, and a wide range of interests. ${ }^{4}$ The application of parenting is very important, because a mother creates the first environment where their child builds interpersonal relationships. ${ }^{5}$ According to the data issued by the Indonesia Demographic and Health Survey (Sensus Demografi Kesehatan Indonesia), in 2010 there were 26.09 million children between the ages of 0 , and 6.13 .5 million children were between the ages of 0 and 3 , and 12.6 million were either 4 or 5 . Approximately $14.8 \%$ of all children experience some form of developmental delay. ${ }^{6}$

The democratic style of parenting prioritizes the child's necessities. Parents who utilize this behavior attempt to use rationality in all of their decisions. They view their child's abilities realistically and do not ask too much of their children. Those who practice the democratic style also give freedom to their children to make their own decisions. The democratic approach is also considered to be warmer. ${ }^{7}$ Characteristics of democratic parenting include making rules approved by both parents and child; administering discipline consistently, the parents viewing discipline as part of love; children having the freedom to express opinions, feelings, and wishes; children learning to respond to the wishes of others; encouraging children to practice independent thinking, responsibility, and self-confidence. ${ }^{8}$

The permissive style of parenting is characterized by allowing children to do things without sufficient monitoring. Parents who practice this style provide their children with minimal guidance, or admonishment. This style tends to be their child's favorite. ${ }^{9}$ Main characteristics of permissive parenting consist of parents who are reluctant to discipline their children, give their child a great deal of freedom, did not set out clear rules or guidelines, did not cor-
Correspondence: Eppy Setiyowati, Faculty of Nursing and Midwifery, Universitas Nahdlatul Ulama Surabaya, SMEA Street 57, Surabaya, Jawa Timur 60243, Indonesia.

Tel: +62318291920 - Fax: +62318298582.

E-mail: eppy@unusa.ac.id

Key words: mother's parenting, child creativity development.

Contributions: the author contributes equally.

Conflict of interests: the author declare no potential conflict of interest.

Funding: the work was supported by Rector of Universitas Nahdlatul Ulama Surabaya.

Clinical trials: the study is registered in ethical committee of Universitas Nahdlatul Ulama Surabaya, identifier no. 081/EC/KEPK/ UNUSA/2018.

Conference presentation: part of this paper was presented at the 3rd International Symposium of Public Health, 2018 October 31- November 1, Universitas Airlangga, Surabaya, Indonesia.

Acknowledgments: the authors would like to thanks to Rector of Universitas Nahdlatul Ulama Surabaya as funding of this research, and to Wonokromo District as a research sites.

Dedication: the article is dedicated to my profession on the occasion of the $3^{\text {rd }}$ International Symposium of Public Health, 2018 October 31- November 2, Surabaya, Indonesia.

Received for publication: 28 July 2019.

Revision received: 9 September 2019.

Accepted for publication: 15 October 2019.

This work is licensed under a Creative Commons Attribution NonCommercial 4.0 License (CC BY-NC 4.0).

(C) Copyright: the Author(s), 2019

Licensee PAGEPress, Italy

Journal of Public Health in Africa 2019; 10(s1):1207 doi:10.4081/jphia.2019.1207

rect their child misbehavior, never place blame on them and parents leave all decisions to children. ${ }^{8}$

Authoritarian style parenting is characterized by limits and guides set out by a parent for their child. Parents who practice the authoritarian style often set rigid limits and do not give their children many opportunities to express opinions. Decisions are made undemocratically, and a child is taught to value whatever their parent values. Children raised in this manner tend to be suspicious of others and have low self-esteem. It's also 
common for these children to feel awkward during interactions with their peers. These children frequently underperform with their academics. ${ }^{10}$

Based on the research problem, we conducted a study on mother's parenting styles and the creativity development in their children. The purpose of this study therefore was to analyze the correlation between parenting style and creativity development in their children.

\section{Materials and Methods}

This analytic study was conducted using a cross-sectional study. The population involved mothers with children between the ages of 4 , and 5 . All mothers involved had children attending the same school in TK RA Al-Islah, A kindergarten located in Patuk, Gempol Sub-district, Pasuruan, East Java Indonesia. From the data, 30 respondents were taken as the samples, using the simple random sampling technique.

The data was analyzed using the chi Square test statistics and the test had a significance level of $\alpha=0.05$. If the test result statistics showed p 0.05 research hypotheses thus < statistics H0 is rejected, and the $\mathrm{H} 1$ is accepted. Which is the correlation between the mother's parenting style, and the creativity development in her child.

Ethical clearance of this research was published by the Ethics Commission of the Universitas Nahdlatul Ulama Surabaya with No. 081/EC/KEPK/UNUSA/2018

\section{Results}

The results show frequency distribution of parenting style, creativity development and the correlation between parenting style and child creativity at TK RA Al-Islah, Patuk, Gempol Sub-district, Pasuruan.

Based on Table 1, it showed that nearly half of mothers $(40 \%)$ practiced a permissive parenting style, compared with other parenting style.

Based on Table 2, it showed that more than half children $(56.7 \%)$ had a low creativity development.

Table 3 showed that 7 mothers practiced democratic parenting and more than half of their children had high creativity development (Table 4).

\section{Discussion and Conclusions}

The study in Table 1 shows that 12 respondents applied the permissive parent- ing style. Based on questionnaire results, mothers tend to interact with their children only when their children need their parents, gave their children freedom and fewer rules. Children raised in this style were expected to understand their parents' expectations because children at that age are very curious. Permissive style parenting allows children to do things without sufficient monitoring from parents.

Some factors that affect parenting are education, occupation, and age. Table 4 shows that most of the respondents $(70.0 \%)$ are between the ages of 20, and 35, which is believe to be both sufficiently mature, and emotionally stable individuals. At this age, mother has an intermediate level of knowledge in parenting which acquires knowledge from their surrounding culture and their experiences. ${ }^{11,12}$

Table 2 showed that most respondents $(56.7 \%)$ had low creativity development. Children with low creativity development are likely to be less active and more skeptical. Hence, parents should always give their children enough attention, and stimulation.
This can improve their child's creativity development. Yet, child creativity can be stimulated by parents and teachers through certain good habits. Children should be taught to deal with specific issues and activities so they can participate in handling and solving problems. Thus, it can develop and optimize their creativity through their pattern of thinking, imagination, and fantasy. ${ }^{11,12}$

Table 3 showed that 7 respondents practiced democratic parenting and children with high creativity development. The table showed that democratic parenting provided children with an opportunity to express themselves. Democratic parenting also provides children with a chance to participate in decision making. Democratic parenting will produce an independent and creative child. One who can control themselves, and build a good relationship with others.

In contrast, authoritarian parenting style gives their children strict ability to make decisions. Most children raised in this parenting style show a low creativity development and characterized by a cowardice,

Table 1. Frequency distribution of parenting style found at TK RA Al-Islah, located in Patuk, Gempol Sub-district, Pasuruan.

\begin{tabular}{llcc} 
No & Parenting style & Frequency & $\%$ \\
1 & Democratic & 9 & 30.0 \\
2 & Permissive & 12 & 40.0 \\
\hline 3 & Authoritarian & 9 & 30.0 \\
Total & 30 & 100 & \\
\hline
\end{tabular}

Table 2. Frequency distribution of child creativity development at TK RA Al-Islah, located in Patuk, Gempol Sub-district, Pasuruan.

\begin{tabular}{llcc} 
No & Creativity development & Frequency & $\%$ \\
1 & High & 13 & 43.3 \\
2 & Low & 17 & 56.7 \\
\hline Total & 30 & 100 & \\
\hline
\end{tabular}

Table 3. Cross tabulation of the correlation between parenting style and child creativity at TK RA Al-Islah, Patuk, Gempol Sub-district, Pasuruan.

\begin{tabular}{lccc} 
Mother's parenting style & \multicolumn{2}{c}{ Creativity development } & Total \\
& High & Low & \\
Democratic & $7(77.8 \%)$ & $2(22.2 \%)$ & $9 \%$ \\
Permissive & $5(41.7 \%)$ & $7(58.3 \%)$ & $12.0 \%$ \\
\hline Authoritarian & $1(11.1 \%)$ & $8(88.9 \%)$ & $9 \%$ \\
Total & $13(43.3 \%)$ & $17(56.7 \%)$ & $30 \%$ \\
\hline
\end{tabular}

Table 4. Chi square test analysis parenting style and child creativity at TK RA Al-Islah, Patuk, Gempol Sub-district, Pasuruan.

\begin{tabular}{lccc} 
Dependent variable & Independent variable & P (Sig.) & Description \\
Parenting style & Child creativity & 0.016 & Correlated \\
\hline
\end{tabular}


bashfulness, and introvert children. They will also have no initiative, and an inclination to break the norms. A mother who practices permissive parenting will always support their child. They will allow the child to make either positive or negative choices. Regardless of their child's choice, the behavior will be rewarded. Parents who practice permissive parenting will have little to no control over their child's behaviors. This parenting style may cause a child to be impulsive, aggressive, and disobedient. These children will also frequently be spoiled, less independent, and less creative.

\section{References}

1. Dembo R, Briones-Robinson R, Barrett $\mathrm{KL}$, et al. Parenting Practices among Biological Mothers of Drug-Involved Truant Youths: A Latent Profile Analysis. Journal of Child \& Adolescent Substance Abuse 2015; 24:282-294.

2. Kim SY, Wang Y, Shen Y, et al. Stability and Change in Adjustment Profiles Among Chinese American Adolescents: The Role of Parenting. Journal of Youth and Adolescence 2015;44:1735-1751.

3. Hirschler-Guttenberg Y, Feldman R, Ostfeld-Etzion S, et al. Self- and Coregulation of Anger and Fear in
Preschoolers with Autism Spectrum Disorders: The Role of Maternal Parenting Style and Temperament. Journal of Autism and Developmental Disorders 2015;45:3004-3014.

4. Rubin M, Kelly BM. A cross-sectional investigation of parenting style and friendship as mediators of the relation between social class and mental health in a university community. International Journal for Equity in Health 2015;14:87. Available from: https:// doi.org/10.1186/s12939-015-0227-2. Accessed on: 10 April 2018.

5. Winer JP, Parent J, Forehand R, et al. Interactive Effects of Psychosocial Stress and Early Pubertal Timing on Youth Depression and Anxiety: Contextual Amplification in Family and Peer Environments. Journal of Child and Family Studies 2015;25(5):13751384.

6. September SJ, Rich EG, Roman NV. The role of parenting styles and socioeconomic status in parents' knowledge of child development. Early Child Development and Care 2016;186:10601078.

7. Egberts MR, Prinzie P, Deković M, et al. The prospective relationship between child personality and perceived parenting: Mediation by parental sense of competence. Personality and
Individual Differences 2015;77:193198.

8. Miguel I, Valentim JP, Carugati F. Social representations of the development of intelligence, parental values and parenting styles: a theoretical model for analysis. European Journal of Psychology of Education 2013;28: 1163-1180.

9. Muhtadie L, Zhou Q, Eisenberg N, et al. Predicting internalizing problems in Chinese children: The unique and interactive effects of parenting and child temperament. Development and Psychopathology 2013;25:653-667.

10. Olivari MG, Tagliabue S, Confalonieri E. Parenting Style and Dimensions Questionnaire: A Review of Reliability and Validity. Marriage \& Family Review 2013;49:465-490.

11. Fearon DD, Copeland D, Saxon TF. The Relationship Between Parenting Styles and Creativity in a Sample of Jamaican Children. Creativity Research Journal 2013;25:119-128.

12. Goodkind J, LaNoue M, Lee C, et al. Involving parents in a communitybased, culturally grounded mental health intervention for American Indian youth: parent perspectives, challenges, and results. Journal of Community Psychology 2012;40(4):468-478. 